\title{
The rural transition - Landwirstchaftliche Produktionsgenossenschaften and landscape before and after German Reunification (1990).
}

\author{
Vittoria Capresi $^{1,1}$, Emily Bereskin ${ }^{1,2}$, and Christoph Muth ${ }^{1}$ \\ ${ }^{1}$ Technical University Berlin, Habitat Unit - Chair of International Urbanism and Design \\ ${ }^{2}$ Université libre de Bruxelles, Faculty of Architecture La Cambre-Horta, HABITER Study Center
}

\begin{abstract}
This paper presents the case study of the MODSCAPES Technische Universität Berlin team: the Landwirtschaftliche Produktionsgenossenschaften - LPGs (agricultural production collectives) of the former German Democratic Republic in the southern Oderbruch (Brandenburg). The paper is divided into two parts: The first discusses the planning and socio-economic theory of the LPGs developed by the East German state, and the ensuing spatial manifestations of these production-and eventually, settlement-schemes. Here, the major differences between the planned vision and the lived reality of these rural networks are highlighted. The second section analyses the post-Reunification development (after 1990), focusing on the former model LPG based in Golzow: we examine the legal procedures guiding the economic transition from socialism to capitalism, as part of the German Reunification (and inclusion in the European Community). We argue that in this period agricultural production has grown even larger in scale through new waves of modernization processes; and most significantly, that this subsequent wave of technological modernization capitalizes on the spatial legacy of the LPG.
\end{abstract}

\section{Introduction}

This paper outlines the TU-Berlin team's ongoing research on the Landwirtschaftliche Produktionsgenossenschaften - LPGs (Agricultural Production Cooperatives) of the former German Democratic Republic $(\mathrm{GDR})^{2}$. Here we present our current lines of

\footnotetext{
1 Corresponding authors : vittoria.capresi@tu-berlin.de, e.bereskin@tu-berlin.de, c.muth@campus.tu-berlin.de

${ }^{2}$ In the frame of the project MODSCAPES, Vittoria Capresi, Emily Bereskin and Christoph Muth, the TU-Berlin team affiliated to the Habitat Unit, is investigating the modern landscape in the southern Oderbruch region. Focus of the research is the LPG Golzow (initially called LPG Einheit), as well as the LPG Walter-Ulbricht, situated directly to the East of Golzow. Research thus far has consisted of an initial archival analysis of documents and maps, a typological study of LPGs buildings in the area, the mapping of current uses, and an initial round of interviews. Further research will continue over the upcoming year.
} 
investigation based on our research in the southern Oderbruch, an agrarian region bordering Poland and approximately eighty kilometers to the east of Berlin. Through an examination of the LPG Golzow, we show how the LPG system transformed rural landscapes during the period of the GDR and discuss the impact of these changes on further transfigurations that have occurred since German Reunification in 1990.

The paper is divided into two parts: first, we examine the history and planning of the LPGs, looking specifically at the LPG Golzow to discuss the discrepancies between planning and practice in village development. Our research thus far indicates that the LPG played a fundamental role in the spatial and social development of the village. Through bargaining mechanisms, both directly with the party, as well as with other organizations, the LPG was often able to secure and provide necessary items and infrastructure to village residents. The second half of the article outlines some of the many new challenges facing the region after 1990. Here, we aim to highlight the continuities that survived this historical rupture, arguing that although economic and political conditions shifted radically, the specific environmental changes that occurred during the GDR had a determining influence on the post-1990 developments. In other words: the expanses of land created by the LPG established the necessary conditions for contemporary modes of automated agricultural production, which themselves reinforce contemporary social and economic challenges. We examine the increased disconnection felt among residents toward regional agriculture as a result of privatization and increased modernization and some of the consequences perceived by local inhabitants stemming from the dissolution of the LPG system.

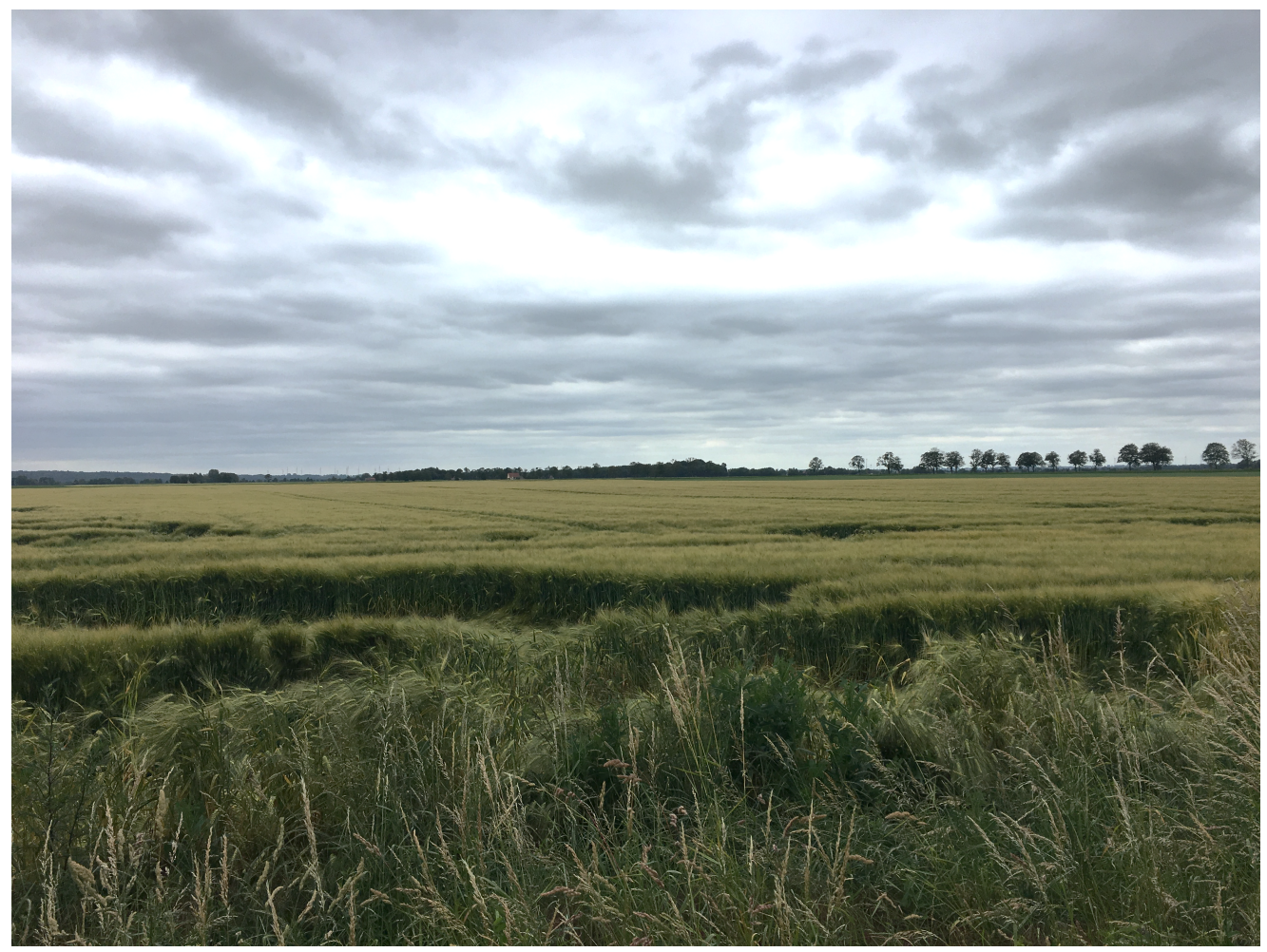

Fig. 1. The south Oderbruch (Brandenburg). Photo: Christoph Muth, 2018. 


\section{Landwirtschaftliche Produktionsgenossenschaften: planning and practice}

After the surrender of the German military in World War II, the country was subdivided into four occupational zones, with the eastern sector being placed under the Soviet Military Administration (SMAD). The SMAD strongly proclaimed the beginning of a new socialist era and promoted values and policies similar to those practiced in the Soviet Union [1: 29]. Two steps would eventually prove critical for the development of rural areas in the GDR: the Bodenreform, or agrarian land reform, issued on September 2, 1945, and the installation of collectivized farming beginning in July 1952.

In September 1945, the SMAD became the first of the four occupying powers to initiate a radical land reform policy (Bodenreform). Under the rallying cry Junkerland in Bauernhand ("The lands of noblemen belong in the hands of farmers"), any property larger than 100 hectares or which belonged to anyone associated with the National Socialist regime was expropriated and transferred into a central pool from where it was then redistributed [2: 96-97]. Under this policy, approximately 3.3 million hectares of land was confiscated. One-third of the land annexed was used by state-led farms (Volkseigene Betriebe-VEBs); the other two-thirds was distributed in small parcels of 5-10 hectares to families and individuals to be used for subsistence farming [3].

In 1947, the SMAD issued Order 209, which outlined measures for economic recovery in rural areas. This directive set quotas for the number of new farmsteads to be constructed in each region and granted farmers the right to collect construction materials from destroyed edifices in order to build new homes. Moreover, farmers were accorded the license to destroy former manor homes for construction material, giving the reconstruction process a clear ideological slant [4: 103]. For the new plots, the state proposed a variety of typologies for new farmsteads (Neubauernstelle) that could be built incrementally as more material became available. Following these schemes, farmers would first build emergency structures, then small barns, and then finally more permanent structures that often combined living spaces with areas for housing livestock under one roof ${ }^{3}$.

In the eyes of the SMAD, the Bodenreform was imperative in order to secure a consistent food supply for the populations. Moreover, it was a distinctly ideological policy: by bringing an end to large-scale land ownership in the hands of only a few individuals, the Bodenreform was a necessary step on the path toward a new socialist society [6: 17]. However, the link between the Bodenreform and the full collectivization of agriculture is less clear. The plots of land distributed under the Bodenreform were often too small to guarantee subsistence. In their respective works on the history of the LPGs, Bauernkämpfer and Schöne both argue that this deficiency was premeditated by the SMAD in order to force cooperation and the pooling of resources and that the Bodenreform was ultimately designed to fail in order to later legitimate the practice of collectivization [6]. In contrast, Dix argues against this notion of premeditated failure, citing the fact that the specific plans for the Bodenreform farmsteads were based on research already conducted as early as the 1920s and were based on proportions not designed by the SMAD [4].

During the post-war period, rural areas faced numerous challenges: due to continuous waves of both in and out migration and a high mortality rate, the population was not stable; many new settlers were not qualified to work as farmers; and the tools and animals necessary to start production were scarce. Amidst these uncertainties,

${ }^{3}$ See for example [5]. 
the government began in 1952 to steer agricultural production toward collectivization. There were three principal types of LPGs: Type 1 involved the collectivization of land; Type 2, the collectivization of means of production including machinery and farm animals; Type 3, the full collectivization of all resources, including livestock and buildings [6: 26]. Throughout the 1950s, various forms of pressure were exerted on reluctant farmers, and full collectivization was forcefully imposed in the so-called "socialist spring" of 1960 [6: 179] $]^{4}$.

From that point onward, the state fostered intensive modernization schemes in rural areas, which coupled with new experiments in modes of production, created a new form of industrial agricultural production. The economic restructuring was accompanied by the introduction of new "urban" lifestyles into rural regions. As members of the local cooperative, farmers now worked as employees: as such, they were entitled to take holidays, receive social benefits, collect a pension, and access the many cultural and health care facilities offered by the cooperative [7: 179].

This period radically influenced the design and shape of rural regions. Towns were transformed by new morphologies and programs: traditional plot divisions and settlement patterns were disregarded in order to reconfigure residential areas through the construction of multi-storey residences and new cultural and service facilities ${ }^{5}$. Individual plots of land were merged into larger areas that could be worked more effectively with large-scaled machinery. Plots were linked via amelioration and drainage projects, and separation barriers such as trees, vegetation, roads, and buildings were often removed [9].

Although in theory all LPGs would be developed equally, there were significant disparities among them in terms of production rates, economic successes, and developmental impacts. Established in 1952, the LPG Golzow became a very successful LPG in the GDR, earning the distinction of "model LPG" (Muster LPG) and drawing international attention. From an initial ten members and an area of 56 hectares, the LPG had grown to 7300 hectares and 600 members by the time of reunification [10]. Our examination of the LPG Golzow illustrates how a centrally planned system was modified in application and highlights the importance of local actors in the negotiation of resource acquisition.

Starting from 1959, the LPG Golzow was led by Arthur Klitzke, a farmer from Golzow himself. In contrast to other LPG-directors, who were often party functionaries simply "parachuted in" by the SED, Klitzke, as a local with a background in agriculture, possessed the expertise necessary for effectively working the land. Under his leadership, the LPG's production rates increased dramatically, which encouraged the SED to send even more experts to work in Golzow, once again furthering the LPG's success rate ${ }^{6}$. This economic success meant that Klitzke was granted a certain degree of freedom to further develop the cooperative and the surrounding village as he saw fit. According to a former administrator, Klitzke often repeated, "So long as you fulfil the quotas, you can do whatever you want ${ }^{7}$ ".

\footnotetext{
${ }^{4}$ For a detailed description of the collectivization process see [7: 179].

${ }^{5}$ For some outstanding examples about the approach of reconstruction of new facilities in historical contexts see [8].

${ }^{6}$ Interview with former LPG Administrator, May 2018.

7 "Wenn du die Pläne erfüllst, dann kannst du machen was du willst.", interview with former LPG Administrator, May 2018.
} 
Economic success also translated into political capital; Klitzke was able to leverage the strategic importance of the LPG to improve the village of Golzow and its surrounding area $^{8}$. For example, as a model LPG, Golzow was used to showcase the successes of cooperative farming to eminent international visitors such as Yasser Arafat (1978) or Kim II Sung (1984). Prior to such visits, civil servants would visit Golzow to ensure the orderly appearance of the town and the farms. On each occasion, Klitzke advised the use of a different route for the guests. He intentionally chose streets in particularly bad condition, so that the civil servant responsible would file an immediate order to upgrade the so-called "protocol route". In this manner, roads would be repaired and paved, street lights would be erected, and the streetscape would be beautified through plantings and other additions [11].

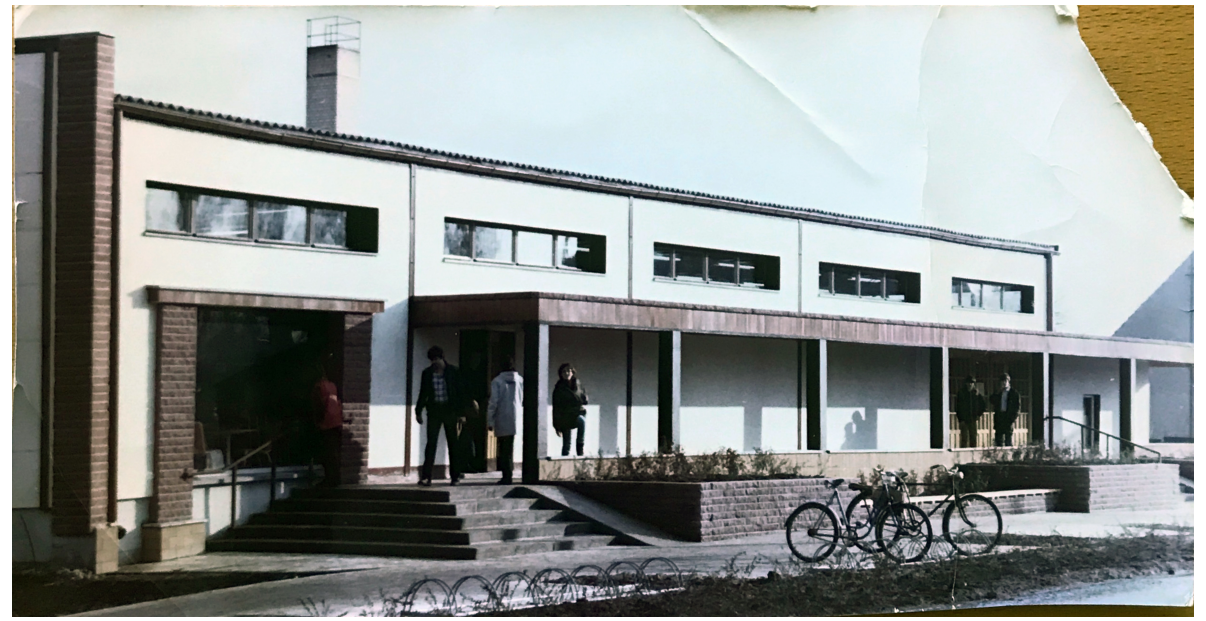

Fig. 2. The former supermarket when in use.

Source: Archive of the Gemeindezentrum (Community Center), Golzow.

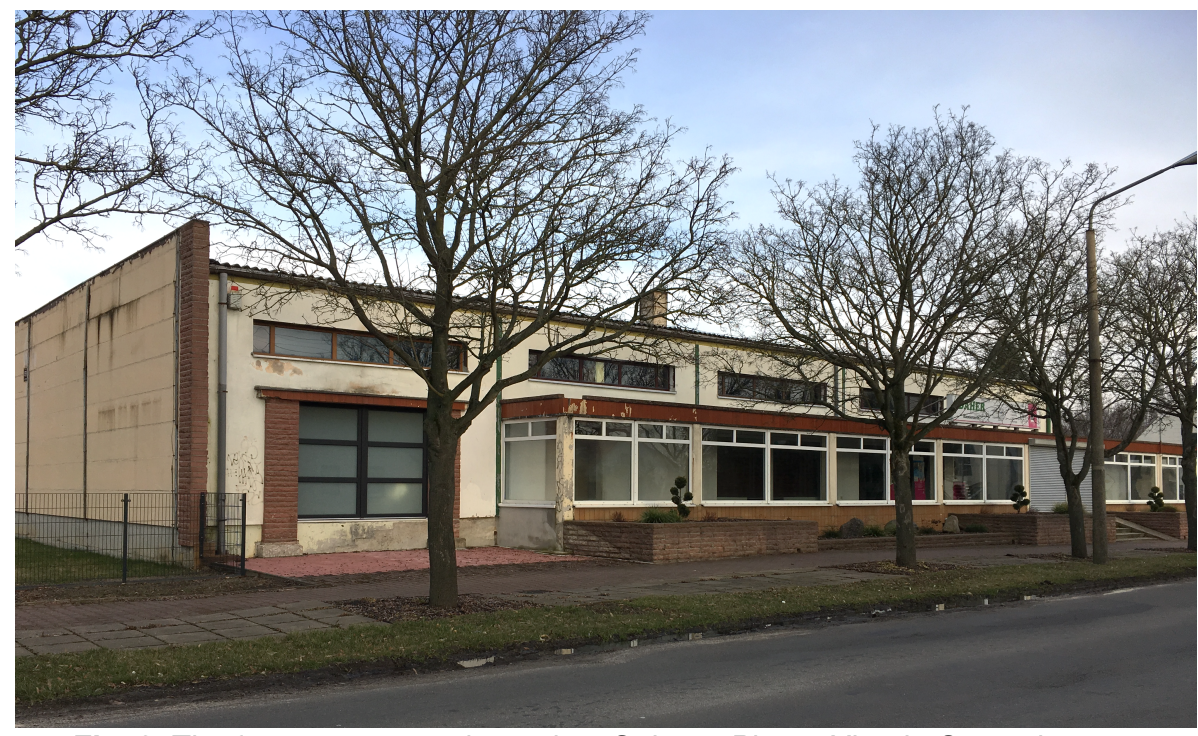

Fig. 3. The former supermarket today, Golzow. Photo: Vittoria Capresi, 2017.

\footnotetext{
${ }^{8}$ This information emerged from interviews with inhabitants of Golzow. Similar stories can also be found in [11].
} 
Klitzke also negotiated for the erection of new structures necessary for the town's development. For instance, according to our interview partners, Klitzke wanted to ensure the presence of basic facilities within the village, so that that employees would not have to take time off work to travel to access good and services. To this end, Klitzke ordered the construction of a supermarket in the center of the village, one planned by the LPG's department of construction and executed by its own construction team. Golzow had not been designated to receive a supermarket, so Klitzke submitted a building permit application for a sheep stall in order to avoid bureaucratic complications. Our interview partner confessed that when he submitted the papers at the construction agency, "everybody knew what it was about". Examples like this indicate that authorities granted exceptions to help socially and economically prominent LPGs ${ }^{10}$.

In interviews, former employees of the LPG involved in all levels of production in the LPG, from farmers to administrators, repeatedly stressed Klitzke's importance in the success of the LPG and in town's development. This is in contrast to the other LPGs found in the region which were much less successful. In practice therefore, regional development was often dictated by the ability to negotiate for resources with the party and to secure resources through internal bargaining among organizations - and both of these practices were ultimately impossible without local expertise that could secure economic success.

\section{The transition from state socialism to capitalism: changes and challenges}

The German Reunification in October 1990 instigated the political and economic transition from state socialism to capitalism and had profound impacts on life throughout the former East Germany. As farming was decollectivized, rural areas were subjected to numerous changes in quick succession that affected property, employment, and agricultural policies. We now turn to examine the legacy of the LPG on the current land administration and production in our case-study area.

Initiated in June 1990, the legal transition of the agricultural sector was regulated by the Landwirtschaftsanpassungsgesetz (Law for Agricultural Adaptation). As the title of the law suggests, it aimed to adapt the GDR's agricultural sector to the marketeconomy ${ }^{11}$. The law consists of two parts: the first organized the legal relationship between the (former) LPGs and their members in order to guarantee that all former members or their successors will be given full legal ownership of their previously pooled land. Plots that could not be returned to their owner were turned over to the Treuhand, an agency and financial trust created to administer the privatization all former holdings of the GDR. The second part of the law governed the conversion of the LPGs into legal entities that would conform with the economic models found in West-Germany.

In order to remain in operation, the LPGs had to officially change their legal status within eighteen months following the passing of the law. Those that did not meet the

\footnotetext{
${ }^{9}$ Interview with former LPG Administrator, May 2018.

${ }^{10}$ A more detailed research on the gaps between official rules and local practices by Dr. Maria Hetzer is ongoing in Golzow, in the framework of the DFG research project "Rooms: Manövrierräume im Staatssozialismus: Zwischen Aneignung und Experiment", University of Vienna, project number: 277133236.

${ }^{11}$ Author's translation. The original title of the law is: Gesetz über die strukturelle Anpassung der Landwirtschaft an die soziale und ökologische Marktwirtschaft in der Deutschen Demokratischen Republik. Retrieved from: https://www.gesetze-im-internet.de/lanpg/_[available on 26 March 2018].
} 
requirements by that time were dissolved and transferred-along with all of their land holdings - to the Treuhand. However, due to legal complications over ownership rights, nearly thirty years later, lawsuits are still ongoing [12].

In 1990, the LPG Golzow was converted into the Landwirtschaft Golzow, Ltd. In December 2012, this company merged with the Odega Group, the largest agricultural enterprise in the Oderbruch region (itself a registered cooperative that came from an LPG conversion). The Odega group is responsible for approximately 17,000 hectares of land and 200 employees [13, 14], double the geographical area of the LPG Golzow, with only one-third the number of employees. This transformation was made possible by significantly streamlining production lines and by outsourcing all possible jobs.

Since the 1990s, the market value of the LPGs has remained comparatively lower than farms in the former West Germany, which has made them extremely attractive to outside investors $^{12}$. However, at the time of their dissolution, most LPGs suffered from years of poor maintenance and new buyers have had to invest heavily in order to modernize their production sites. East German properties therefore garnered the attention of investors looking to make use of the EU's Common Agricultural Policy that offered subsidies calculated on the basis of arable surface, and that gave extra funding for modernizing production lines toward organic agriculture and renewable energy [16].

This new structural background has led to the develop of what Ludger Gailing has termed "energy landscapes" [17]. Such landscapes are categorized either by the dominance of crops such as corn or rape seed, which are used to produce the base material for the production of biogas, or by technical elements such as solar farms, wind parks and biogas tanks. In the Oderbruch, as well as throughout the former GDR, these new products have slowly replaced traditional agricultural lines as they guarantee higher revenues and long-term price stability [18]. Moreover, such crops require less labour in comparison to vegetable cultivation. Traditional crops in the Oderbruch, such as tomatoes, cucumbers, and sugar beets are therefore no longer competitive and are almost no longer to be found. Animal and dairy farms have also almost completely shut down across the region [14].

In addition to the structural changes in the agricultural sector, the demographics and social structure in the region is also changing significantly. An aging population, school closures, suspension of public transport service and a decreasing availability of commercial facilities, characteristics of the phenomenon on shrinking villages, pose new challenges for the residents of Golzow and the surrounding area.

Before reunification, the LPG Golzow managed all different branches of the production-from planting to selling the crops, from running workshops to preparing meals for the employees. Parallel to that, the LPG was supporting its staff by providing housing, cultural and educational activities and taking an active role in shaping the townscape. After its collapse, these duties have fallen to financially-strapped municipalities. Some Golzowers believe that there is more that Odega could be doing to give back to the communities where the company is active. This perception, whether justifiable or not, has led to a growing divide between the company, the municipality, and local inhabitants. Certainly, as fewer people actually work in agriculture, and as products are increasingly being sent to Berlin and further afield instead of being grown for local consumption, there is now a disconnect between many inhabitants and their productive landscape.

\footnotetext{
${ }^{12}$ The low market price was the results of multiple factors. One was the policy of austerity during the GDR: none or little investments were dedicated to update machinery and tools; several LPG weren't economically productive, and received state support. For a more detailed report on this transitional phase, see [15].
} 


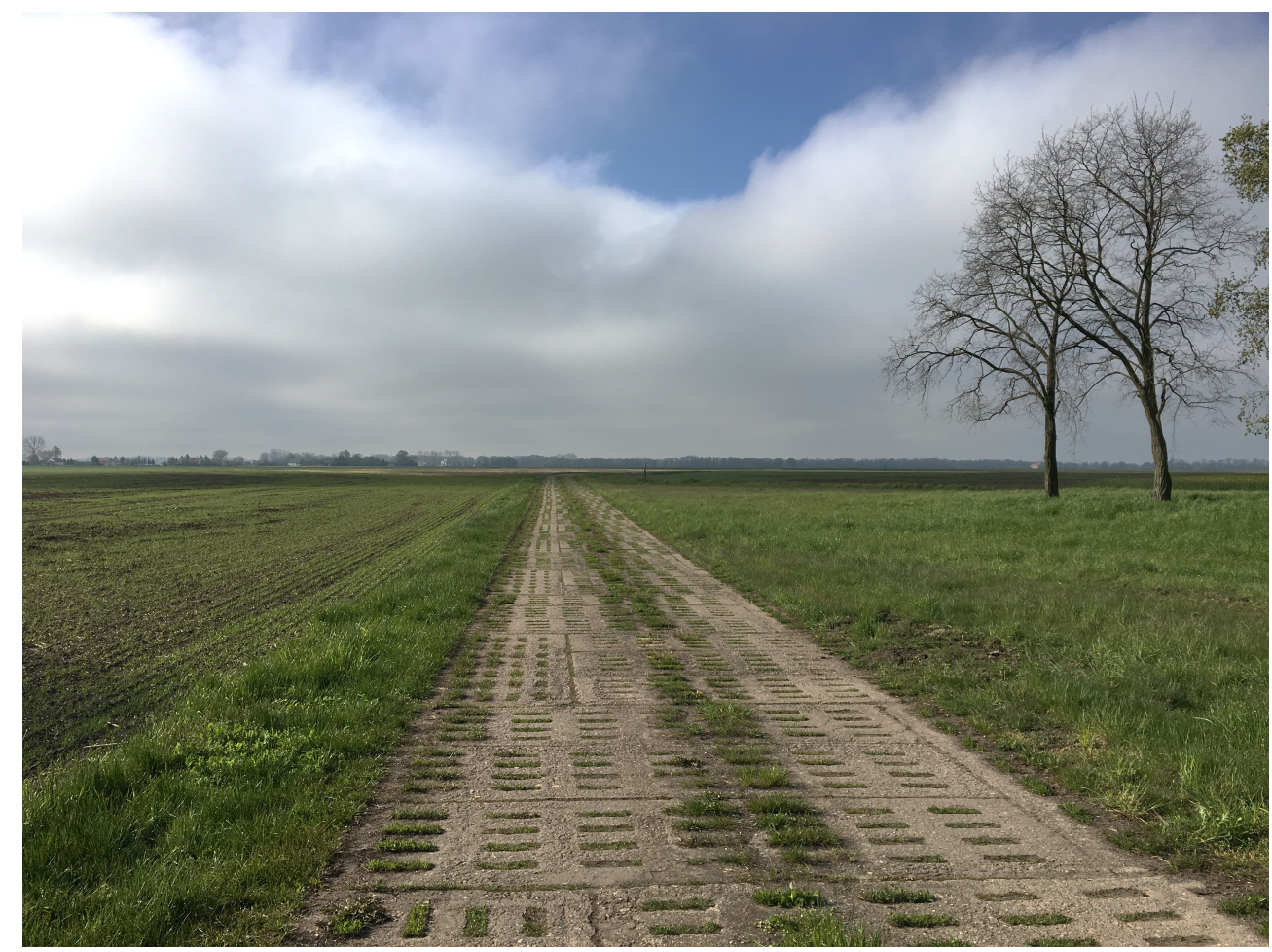

Fig. 4. The south Oderbruch (Brandenburg). Photo: @ Vittoria Capresi, 2017.

\section{Conclusions}

During the GDR, the LPG Golzow was central to communal life. Not only did the LPG manage and provide employment opportunities, it also provided services, constructed housing and infrastructure, and enhanced the social and cultural life of the village. In order to secure a high quality of life for residents, the LPG administration had to negotiate within the party system as well as to creatively pursue alternative paths, such as informal trading or bargaining. This fundamental role ended abruptly with German reunification, the dissolution of the LPG, and its ultimate acquisition by the ODEGA group. In this paper, we have argued that the administration and land management of the former LPG paved the way for the agricultural practices of the current cooperative. However, with the increased scale of production, the automation of various jobs, and the shift toward energy production, many local inhabitants today report feeling alienated from the productive landscapes surrounding their villages ${ }^{13}$.

Still, the future of this landscape remains to be seen. A renewed interest in the area is emerging, due to its favourable geographical position between Poland and Berlin. There is a resurgence in tourism interest, and Berliners are increasingly moving to the Oderbruch to begin new agricultural, artistic, and technological enterprises ${ }^{14}$. How will

\footnotetext{
${ }^{13}$ Several interviews were recorded between March and June, and many of the inhabitants agree in considering this rupture with the landscape a problem in terms of employment and sources, but also in terms of cultural identification with their history and physical surroundings.

${ }^{14}$ The former Gorgast castle is now a hub for non-local people, who bought and restored the complex, attracted from the nature and the possibility to have space for diverse activities (bio production, meetings, discussions). Retrieved from: https://www.gut-gorgast.de/ [available on 22 October 2018].
} 
these new mobilities take hold? Will organic farming and other models provide new alternatives? What's next for this rural landscape?

\section{Acknowledgements}

MODSCAPES is a collaborative research project funded under the HERA - Humanities in the European Research Area 3rd Joint Research Programme dedicated to "Uses of the Past" (20162019). This project has received funding from the European Union's Horizon 2020 research and innovation programme under grant agreement $n^{\circ} 649307$

\section{Short Resumes}

Cristoph Muth (Dipl.-Ing.) is a Doctoral Candidate and external researcher at the Habitat Unit, Chair of International Urbanism and Design at the TU of Berlin since June 2017. His dissertation and research is closely related to MODSCAPES, focusing on the German case study of the Oderbruch area. From 2015 to 2017 Christoph was Instructor at the German University in Cairo (GUC), Department of Architecture and Urban Design, and the outcome of his teaching activities was featured as part of the permanent exhibition at the 15th International Exhibition of Architecture - La Biennale di Venezia - in 2016. He also co-founded "100/100", an intercultural platform to foster dialogue and exchange in the discipline of Arabic Design.

Emily Bereskin is currently a postdoctoral fellow at the Habitat Unit, TU of Berlin (she held a similar position at the HABITER Study Center, Faculty of Architecture La Cambre Horta at the Université libre de Bruxelles at time of participating to the conference). Prior to joining the MODSCAPES team, Dr. Bereskin was a DFG (German Research Foundation) fellow for the international graduate program "The World in the City - Berlin, New York, Toronto" at the Center for Metropolitan Studies, Technische Universität Berlin. She also lectures at Norwich University's Citylab Berlin and the Technische Universität's Master's Programme in Urban Management. Dr. Bereskin received her Ph.D. in Art History from Bryn Mawr College.

Vittoria Capresi has been senior researcher at the Habitat Unit at the TU of Berlin since October 2016, as a PI of the International European Project MODSCAPES. Vittoria studied architecture at the University in Florence and at TU in Berlin, before moving to Vienna as a Teaching Assistant at the TU Vienna's department of History of Architecture (2002-2011). There, she was awarded her PhD, which was published in 2010: The built Utopia. The Italian Rural Centres founded in Colonial Libya 1934-1940. Bologna, BUP. From 2011-2014 she was Associate Professor in History of Architecture and Urban Design at the German University in Cairo-GUC.

\section{References}

1. KIND, G. 1997. "Territorialentwicklung und Territorialplanung in der DDR", in A. Becker (ed), Regionale Strukturen im Wandel, Opladen, Leske und Budrich: 17103. DOI: https://doi.org/10.1007/978-3-322-97367-2_1

2. HEREDIA, S.; KLÄNER, M. de; 2015. "Bodenreformgesetzgebung in den Westzonen", in Projektgruppe Umsiedlerin (ed.), Transitzone Dorf - Ein Ort zwischen Bodenreform und Kollektivierung, Leipzig, Zank Verlag: 93-100.

3. VON ALVENSLEBEN, R. 1990. "Probleme der DDR-Landwirtschaft", Wirtschaftsdienst, vol. 70, n 8: 406-410. DOI: https://doi.org/10419/136666

4. DIX, A. 2002. "Freies Land" Siedlungsplanung im ländlichen Raum der SBZ und frühen DDR 1945-1955, Köln - Weimar - Wien, Böhlau.

5. WEISE, R. 1947. Das Bauen auf dem Lande, Rostock, Carl-Hinztorff Verlag. 
6. SCHÖNE, J. 2005. Die Landwirtschaft in der DDR 1945-1990, Erfurt, Landeszentrale für politische Bildung Thüringen.

7. SCHÖNE, J. 2014. "Ideology and Asymmetrical Entanglements", in A. Bauerkämpfer; C. Iordachi (eds.), The Collectivization of Agriculture in Communist Eastern Europe: Comparisons and Cross-Border Entanglements, BudapestNew York, Central European University Press: 147-180.

8. NIEMKE, W.; GRÜNBERG, H. 1959. ALTE DÖRFER - NEUE DÖRFER: Anleitung zur Dorfplanung in der Deutschen Demokratischen Republik, Berlin, Ministerium für Bauwesen der Deutschen Bauakademie und des Ministeriums für Land- und Forstwirtschaft Sektor Agrarpropaganda.

9. CORDS-PARCHIM, W. 1954. Der Landbaumeister, Radebeul-Berlin, Neumann Verlag.

10. Golzow Ort der "Kinder von Golzow" (n.d.). Web page. Retrieved from: https://www.amt-golzow.de/verzeichnis/objekt.php?mandat=52510 [available on 26 March 2018].

11. SUTHAU, W. 2008. "Episoden von den Staats- und Regierungsbesuchen in der LPG 'Golzow' Golzow”, in 700 Jahre Golzow 1308 - 2008, Gemeinde Golzow: 69.

12. BEYERLEIN, A.; KLESMANN, M.; SCHWENKENBECHER J. 2008. "Bauernland in Erbenhand - BGH-Schelte wegen Umgangs mit Bodenreformland Brandenburg will Streitfälle schnell klären”, Berliner Zeitung, $n^{\circ}$ 31, 6 February. Rerieved from: https://www.berliner-zeitung.de/bgh-schelte-wegen-umgangs-mitbodenreformland---brandenburg-will-streitfaelle-schnell-klaeren-bauernland-inerbenhand-15552780 [available on 12 January 2019].

13. GRIEGER, U. 2018. "Ein schwieriges Wirtschaftsjahr", Märkische Oderzeitung (MOZ), 10 January. Retrieved from: https://www.moz.de/artikelansicht/dg/0/1/1630096/ [available on 12 January 2019].

14. GRIEGER, U. 2016. "Odega-Gruppe feiert die Ernte", Märkische Oderzeitung (MOZ), 7 November. Retrieved from: https://www.moz.de/artikelansicht/dg/0/1/1528446/ [available on 12 January 2019].

15. BAYER, W. 2012, Gutachten: Die Umwandlung der LPGen im Land Brandenburg, (Report to the 22nd meeting of the Brandeburg Landtag's EK 5/1 Inquiry commission, 15 June 2012). Retrieved from: https://www.landtag.brandenburg.de/de/22._sitzung_der_enquetekommission_5/1_am_15.06.2012/bb1.c.297321.de [available on 12 January 2019].

16. BUNDESMINISTERIUM FÜR ERNÄHRUNG UND LANDWIRTSCHAFT (2015). Grundzüge der Gemeinsamen Agrarpolitik (GAP) und ihrer Umsetzung in Deutschland. Web page. 5 January. Retreived from: https://www.bmel.de/DE/Landwirtschaft/Agrarpolitik/_Texte/GAPNationaleUmsetzung.html [available on 22 October 2018].

17. GAILING, L. 2017. "Die neuen ländlichen Energieräume: Kulturlandschaften der Energiewende", Ländlicher Raum, vol. 68, $\mathrm{n}^{\circ}$ 1: 43-45. Retrieved from: https://www.asg-goe.de/pdf/LR0117.pdf [available on 12 January 2019].

18. GAILING, L.; LEIBENATH, M. (eds.) 2013. Neue Energielandschaften - Neue Perspektiven der Landschaftsforschung, Wiesbaden, Springer Verlag. DOI: https://doi.org/10.1007/978-3-531-19795-1 